\title{
DIMENTIONS OF CONTEMPORARY POSTMODERN PILGRIMAGE AS GLOCAL RELIGIOUS CULTURAL HERITAGE
}

\author{
Liana Galabova \\ Independent Researcher, Sofia, Bulgaria \\ lianagalabova@abv.bg
}

\begin{abstract}
Contemporary practices of recreational and confessional travel and visit of sacred sites of various denominations focus multitude of orientations and attitudes regarding religious cultural heritage. Postmodern tourist experience of organisation and research encompasses wide space from local to global, from material to invisible, form forgotten to live heritage, and from sustainable to dynamic, from subjective to generally valid, acknowledged, and human in religious culture and everyday life. Transmission of traditional values and rituals, as well as actualisation of cultural practices basic for religions, confessions, and their communities would be impossible without sacral topoi as a focus of tourist interests, flow of people and dynamic site exploitation, and without development of the reflection on those processes. In regard of adjustment of religious and civic rights, motivations, interests and attitudes for sustainable development and representative identity, not only values of democratic social awareness, geopolitical, national, or ethnic balance are important, but as well the potential of social studies and structures to maintain optimal social policies and care addressing whole variety of uneven statuses.
\end{abstract}

Keywords: Pilgrimage; Hierotopy; Religious Tourism; Glocal Mobility; Postmodern Culture; Sacred Sites; Heritage Perception; Visitor and User Reflections; Responsible and Accessible Tourism; Accommodation and Accessibility of Tourist Sites; Psycho-Somatic Impairments; Social Care.

\section{ИЗМЕРЕНИЯ НА СЪВРЕМЕННОТО ПОСТМОАЕРНО ПОКАОННИЧЕСТВО КАТО ГАОКААНО РЕАИГИОЗНО КУАТУРНО НАСАЕАСТВО}

\author{
Аиана Гъ^ьбова \\ Изследовател на свободна практика, Соория, България
}

\begin{abstract}
Резюме: Съвременните практики на почивно и конфресионално пьтуване и посещение на свети места на размични Аеноминации съсредоточава множество ориентации и нагласи, свързани С религиозното културно наслеАство. Постмодерният туристически оПит в организация И изслеАвания обхваща обширно пространство от местното Ао глобалното, от
\end{abstract}


материалното Ао незримото, от забравеното $А$ живото наслеАСтво, от Устойчивото АО Аинамичното, от субективното АО общовалиАното, общоприетото и общочовешкото в религиозната култура и ежеАневния живот.

Трансмисията на традиционни ценности и ритуали, както и актуализацията на културни практики, базови за религиите, вероизповеданията и общностите биха била невъзможна без сакралните топоси като фокус на туристически интерес, човекопоток и Аинамична експлоатация на обекти и без развитието на рефиексията на тези процеси. С оглеА на съобразяването на религиозни и гражАански права, мотивации, интереси и нагласи за устойчиво развитие и престижна иАентичност, не по-малко важни от ценностите на Аемократично обществено съзнание, геополитически, национален и етнически баланс, са възможностите на обществените науки и структури за оптимални социални политики и грижи, насочени към цялото разнообразие от неравнопоставености.

КАючови Ауми: Поклонничество; Йеротопия; Религиозен туризъм; ГАокална мобилност; Постмодерна култура; Свещени места; Възприемане на наследството; Посетителски и потребителски рефлексии; Отговорен и Аостьпен туризъм; Приспособяване и Аостьпност на туристически обекти; Психосоматични уврежАания; Социални грижи;

Local church pilgrimage in Bulgaria along centuries had been following and developing strict rules of rich live heritage of glocal religious traditions, parallelly reaching modern and postmodern transformation of 20th century and looking like setting of new and completely different cultural practice. Slight development of expressive forms of church traditions according to glocal cultural identities and changes was often interpreted as religious response, confessional legitimation, denominational consolidation, or civilizational transformation. Pilgrimage as inherited glocal mechanism of socialisation and enculturation plays a role of adjusting of religious lifestyles to their renovating contexts. Therefore postmodern dimensions of Eastern Orthodox Christian church religious tourism require specific scholarly attention not only through high philosophical perspective on postmodern radical theology (Caputo, 2015). Disputable relation of Christianity with every contemporary culture is not yet expecting from pilgrims or travels in micro level of everyday life to become clearly postmodern in all possible organisational complexity of such change without norms that had already become vague. Dynamic view on pilgrimage matters also in regard of reconsidering traditionalism after civilizational turn expected to be provoked 
by recent crisis to reshape postmodernism as legacy and start a new cultural project.

Research on religious values and attitudes used to be problematic (Garvanova, \& Shapkalova, 2015) already for about a century, not only in Bulgaria, following half a century privatisation of Eastern Orthodox confessional life along modernisation and urbanisation combined with emancipation from church as social factor and reflection, as an emblem and expression of religious convictions, worldview and lifestyle, and resulting in reshaping, reconceptualization, or reorganisation of system of sacred sites (Valchinova, 1999: p. 134). Religious modernisation had been rather spontaneously emerging (Valchinova, 1999: p. 129) even earlier than since more visible Bulgarian secularisation processes in 1920s, and more massively imposed social change after mid-1940s, when to reflect on church life became impossible. Heritage approach to once neglected religious culture and lost instruments to interpret its authenticity improved religious situation from late 1960s until early 1980s, and especially during social transition from late 1980s until 2000s, and contributed to its research, based on advanced medieval and revival studies, besides their ideological abuse.

Artificial and politicised mass revival of numerous old cultural traditions and practices inspired deideologising sectors of education, art, tourism, and regional development, without enough sociological approval and anthropological clarity of their link to contemporary confessional reality, still remaining quite unexplored and unorganised. Low cultural self-esteem and need of more variable and creative expression of glocally reconsidered identity juxtaposed again local and global achievements, where religion was one of elements that caused initial misbalance. Impossibility of direct early 21st century continuation of abruptly stopped development of modernised pilgrimage form the first half of 20th century (Rilets 2015/1939) affected contemporary pilgrimage innovation form religious festival migration to recreational tourist tendencies in travel culture.

In strict ascetic sense pilgrimage used to be traditional alternative to recreation and sports, and although elite visits of donators and authorities to sacred sites were honourable (Koleva, 2011), on mass popular level religious travel was not always festive, pleasant and healthy (Rilets, 2015/1939), but rather hard, risky, and sacrificial, even when it aimed healing, social prestige, and redemption. While hierotopy of sacred space was supposed to 
encompass and transform not only tourist sites, but whole landscapes, countries, regions, and continents, Bulgarian practice needed some time to revive at least partially the hidden religious live, relink it to tourism in adequate way, and return feast back in local culture in original way, and not by imitation and borrowing of models. Revived parish centres and monastic communities started developing pilgrimage among many other activities that they ran in order to support church charities or just to sustain buildings and liturgical life.

Even if in religious perspective return to authentic traditions would have been considered possible in present day Eastern Orthodox Christian Church, it was a real confessional and cultural feat to link recently any customary law with cannon law. "According to tradition and church rules, girls suited for marriage are not to attend church and visit sacred sites. They go there only for Communion and during Passion Week to kiss Crucifix and Shroud. When girls and boys get married and wedded, they are allowed to church and to attend holly dwellings" (Koleva, 2011: p. 243). Youth pilgrim subcultures for more than a century follow just the opposite model of church mission (Rilets, 2015/1939) providing space for believers to consolidate new families and raise confessionally aware children. Although in the past authorities used, for example festivals of church choirs, to let young people leave monasteries and start families, more recently church youth activities as renovation of abandoned monasteries could often result in joining clergy or cloister.

Cultural practice of pilgrimage had become quite touristic, not only because of more or less natural and spontaneous (Valchinova, 1999: p. 129) processes of modernisation and secularisation, but rather in result of new scope on sacred geographical concepts of Rome, Byzantium, Jerusalem, Athos, and rethinking of their initial pan-orthodox value along wars and church splits, ethnofile nationalist rivalries and border changes, persecutions, ghettoization and 20th and 21st century migrations. Holly space - lost, regained, relocated or transformed, ruined or abandoned, vanishing and virtual - is also part of public personification of church and at the same time object of individual contemplation as confessional spiritual sacred travel with a potential to be independent from both tourism and religion, by pilgrim theology, philosophy, narratives, reports, art, and research reflections. 
Every iconoclastic-like period affects sacred sites according to real problems of their accessibility when they have stopped embodying their initial purpose of concentrating genuine confessional teaching and belonging, and started expressing attitudes and worldviews quite different from denominational ethos. Touristification of pilgrimage and museification of religious centres used to be social reaction to asocial and a-cultural effects of stratification of religious communities. As a refined method of secularisation touristification of churches and monasteries nowadays is part of their revival including religious interests and rights, although in the near past sacred museification was also a diplomatic escape from socialist limitation of movement and confession and shifting the focus of rituals to magic rites.

Nevertheless hypermodernisation of religious practices that is expected to follow a-modern aspects of recent pandemic cultural crisis, is providing opportunity of changing on health purpose all problematic elements of rites that follow tradition and at the same time used to endanger even too conditional postmodern spirituality'. Materialist views on religious part of historical cultural heritage should not be disregarded along remodernisation, because they could positively value in resocialisational perspective a number of useful for religion spontaneous secularisation phenomena of reduction of public role of church place as factor and a vitrine of society from function of religious centre representing and reflecting of everyday life as a showcase (Valchinova, 1999: p. 129), and more planned movements as eugenics. Monumentalisation of church as an emblem of nation and ethnos provided cultural emancipation of people

\footnotetext{
${ }^{1}$ Most recent sudden and extreme problem of tourist lifestyle caused by glocal pandemic crisis from spring 2002 resulted in social distancing and quarantine closures that affected almost all public sectors and private lives, especially with regard of organisation of religious sites and communities. Traditionally functioning in cooperation with administration and security authorities and services, with health and social care institutions and organisations, and with child and youth care, and educational systems, religious centres are also cultural spaces of contemplation, socialisation, and worship. Still most of religious communities worldwide did not manage to react quite adequately to rapid and mass epidemiological threads to whole recent human population, including elites and vulnerable social strata. Denomination units became even least to measure appropriately the risks between enjoyment of human rights so that they coincide optimally. Therefore predominantly civic authorities and society could implement any right and immediate decisions to save societal balance and welfare, as well as future missions and public images of denominations and their lifestyles
} 
from religious communities and also legal institutional subordination of church to state on the background of new everyday life (Valchinova, 1999: p. 133), and even if its further renovation would imply ruralisation, patriotic reideologisation, and partial demodernisation in general, religious revival including mobility might not become just a complete tourist historical heritage restoration.

Patrimonisation of religious heritage and memorialisation of its visible side shifted cultural focus from rich variety of live practices to museum enclosure of customs by reduction of activities, relocation of events to private spaces, by rhythm interference by calendar and devotion changes, and deprivation of sacred building personifying communities and values from life, but remained more elegant communist way to overcome religious worldview and practice including pilgrimage, than direct prohibition (Valchinova, 1999: p. 139) that could also spoil international image of the country and of socialist camp in general. Therefore touristification might be sometimes neglected by recent clergy and believers as too material and comercialisable part of religious legacy, although it is still a kind of unconscious aformal representation of faith and education about church that accomplishes its providential function. Socialist sacralisation of regulated access to sacred spaces and specific almost magical perception of poplar practice of visiting churches for quiet personal prayer and candle lighting shared between devoted visitors and guards (Valchinova, 1999: p. 140) passed the stage of noisy crowding of landscapes, churching search, heritage browsing, energetic recharging, patriotic identity affirmation, popular space exploitation, playful communication, and emerged as a combination of both religious inclinations in an extremely polarised pandemic choice between virtual and conscious church belonging and fight for lost material sacredness that had once affected by politicised asocietal canonical lustration split Bulgarian Eastern Orthodox Church community and social cultural unity in early 21 st century.

Reconsideration of accounts form pilgrim travel writing from early Christianity links biblical and church-historical tradition of visiting of places of sacred events and lives of saints with practices of contemplation on sacred burial sites and favourite landscapes inspiring spiritual zeal and providing miraculous healing of mind and body along wish of laity to join monastic ascetic efforts and lifestyle and finally results in contemporary youth and 
family recreation and sportive activities close to nature and church, and incomparable to clerical impressions from religious mobility. Modernised attitudes of elite and ordinary clergy and laity, theologians, and other believers, experts and civic stakeholders or target groups, without regard of scope, scale, and specific favourite pilgrim direction and qualification already sound less normative or like church etiquette guides or catechetic resources. Moreover after decades of repression on human rights including religion and belief, not only tourist legislation, but also travel choices, marketing, and organisation had initially to compensate for persistent already several decades absence of real, actual, and sociable religious life and information, education, and charity and let people free to develop more individual religiousness also such expressed in pilgrimage attitudes (Nikolova, 2013), which is to be considered both economically and theologically. In postmodern perspective pilgrimage tourism is naturally more eclectic activity combining church and secular, high and popular, theological and folk, interconfessional, and interreligious dimensions (Kõiva, 2016), (Radisavlevich-Chiparazovich, 2014), also when it is held by church units as in the past [Fig. 1].
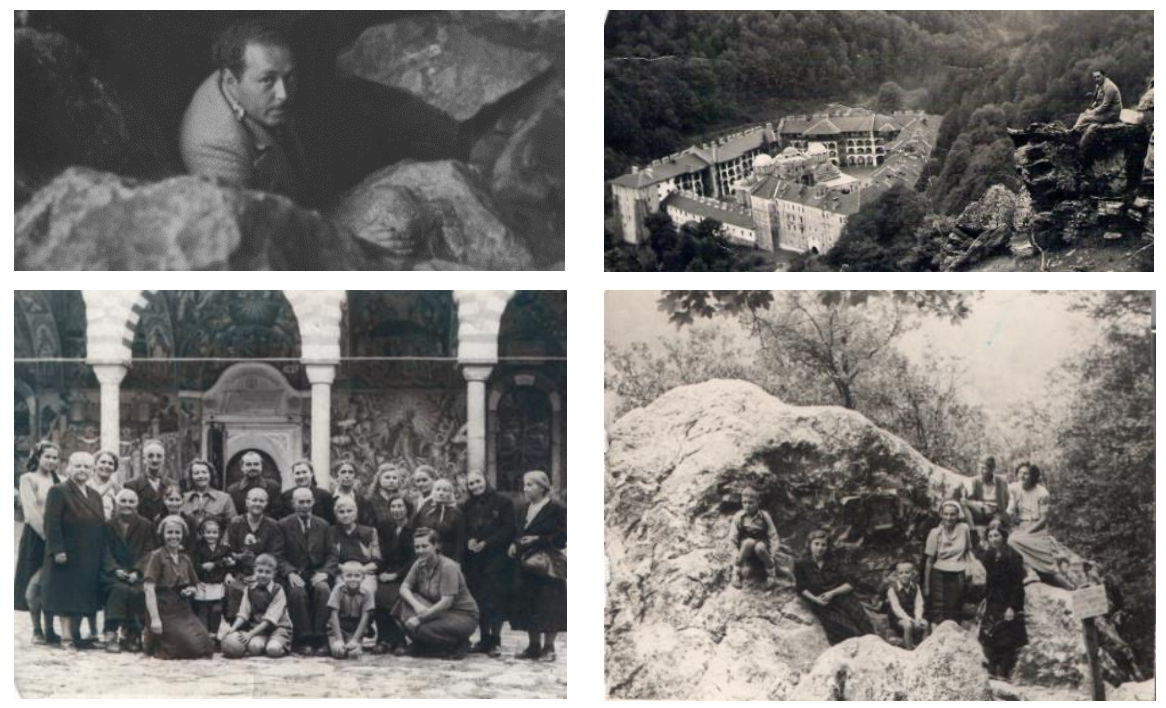

Figure 1. Photos from modernised traditional pilgrimages to Saint John of Rilla stavropegial monastery (mid. of 20th c.); represents church officer, activist and his widowed family with the parish of a central church in Sofia 
In early 1950s during first decade of communist democratisation, children from the photograph remember that pilgrimage trip was an excursion in private neighbourhood circle of a parish of one of the central churches in Sofia - Saint Cyril and Methodius at the Female marketplace. One of the boys had secretly placed stones in the bags of some of women so that they have difficulty in climbing and have fun, while learning that the burden had not actually been in their luggage.

They also remember the prayer rock of the saint, where people used to tie pieces from their clothes on the horizontal string visible on the picture near the icons, doing that for health and good luck and with promise and assurance that they will soon come again to thank saint and God about that. One of the photographed children remembers 70 years later that parish trip as family travel, after the loss of his father in late 1944 and church opportunity of his mother to work as an accountant. Children remember the specific food and accommodation in the monastery, but they do not mention the tree behind the rock with plant bacteria interpreted as drops of the blood of the saint from a moment of his life, although such tree can be seen also in Sofia seminary Saint John of Rilla, and people keep such leaves in their prayer books. Neither people remind of the sand that is usually collected from the stone plate of saint's grave and dissolved in water cures stomach pain, nor they remember more precisely their ritual passage (Bulg. provirane, promushvane) (Kõiva, Kuperjanov, \& Vesik, 2018: p. 125-126) through saint's cave upwards from lower entrance through the stone bed, perceived as table or icon shelf (Bulg. - odarche) looking differently through the time and taken seriously by researchers.

In late 1930s people were usually photographed while appearing at the higher entrance of saint's natural cave that used to be smaller in the past and interpreted as window or chimney, and according to popular belief that sinful people are unable to exit and reach the holly well and the prayer rock of medieval Bulgarian saint protector, children could joke with adults and secretly pull their dress downwards until they publicly confess their sins (Rilets, 2015/1939). Fortunately monks and experts observed and recorded thoroughly pilgrimage attitudes and behaviours of people yet before secret services on security reasons would need that information and actually made one of the best recent research data sources kept and 
available in Police and Military archives, including even small notes or letters left near saints' graves and photographs with transparent copies with inscribed names and dates. While older people having visited Rilla monastery in 20th century remembered also the famous monk-woodcarver, people from mid 1950s have seen the renown icon-painting studio lead by Nikolay Schelechow, and people involved in transformation of sacred site to tourist object in early 1960s remember reorganisation and accomplishments of thorough restoration, and others only mention repressions (Peykov (ed.), 2016: p. 23), observations between early 1920s and late 1930s discuss more tourist organisational and pilgrims pastoral aspects ${ }^{2}$. Contribution not only to historical research, but also to restorative contemporary pilgrimage are precommunist accounts on: qualitative and quantitative characteristics of the dynamics of people flow according to festive calendar, devotions, donations, liturgical participations, virtues and vices, religious needs and expressions, elite and mass recreation, souvenir production, good distribution and even security issues (Rilets, 2015/1939). Old reports contain still adequate decisions of persisting even nowadays problems of some of church folk practices of mass religiousness that let people: unconsciously kiss profane decorative elements as state emblems or negative or neutral personages on icons, do not leave tax, distribute small donation to every saint represented in icon on the templon or kept in believers mind, lit homemade candles, sleep on the balconies, require impossible curse prayer ritual for enemies or dead commemoration for themselves, etc., etc. (Rilets, 2015/1939). Such kind of memories, as well as more mystical account on pilgrimage impressions as sharing feeling, dreams, visions and miracles, could reflect in unpopularity of traditional visit or churches, monasteries, and convents among contemporary sincere and well-informed clergy and believers who would rather travel to participate in liturgical life and help organisation and monastic household as specific king of volunteers (Bulg. harizani or sacredly devoted people) in a kind of postmodern altruistic tourism (Mustonen, 2006). Rich local and regional research on religious heritage (Demirev, 2019), (Demirev, 2014) already encompass at least early socialist period from a number of interesting scopes as for example

\footnotetext{
2 More characteristic to the cult to contemporary saint Seraphim of Sofia as continuation of his live pastoral practice as Russian archbishop in Bulgaria, and his real promised reading of prayer letters as a wise compensation for atheist education that discouraged prayer of people to saints with expectation of their advocacy.
} 
documental studies of 1000-year annual celebration of at Rilla stavropegial monastery (Kalkandzhieva, 2002) in 1940s, and burial gathering of his beatitude last Bulgarian Exarch Stephen in Bachkovo stavropegial monastery in 1950s (Nikolchev, 2015).

Pilgrimage from early 1990s (Velinov, 2012) revived many of new religious traditions that emerged in 20th century in relation to wars and border shifting that change the situation for many people and regions (Valchinova, 2006). At the same time tourist movement was still reflecting traditional and modern cultural lifestyles (Benovska-Sabkova, 2006), transformed festival system was changed again (Simeonova, 2000), as festivals came in support of social change (Benovska-Sabkova, 1998), privatization of many sectors reconsidered social stratification (Luleva, 2012) and reoriented resources and values with regard of pre-communist customs (Rilets 1939) also about pilgrimage donation and environment protection.

Numerous particular topical studies based on only partially preserved and available documentation on church folk traditions, nowadays provide valuable anthropological perspective on processes of transformation and retransformation of devotional and worship practices that become memorialised also as tourist visual communication of the place, as augmented reality, and also by everyday and festive artistic and photographic impressions and micro personal reports on what really happened about religion and belief [Fig. 2].
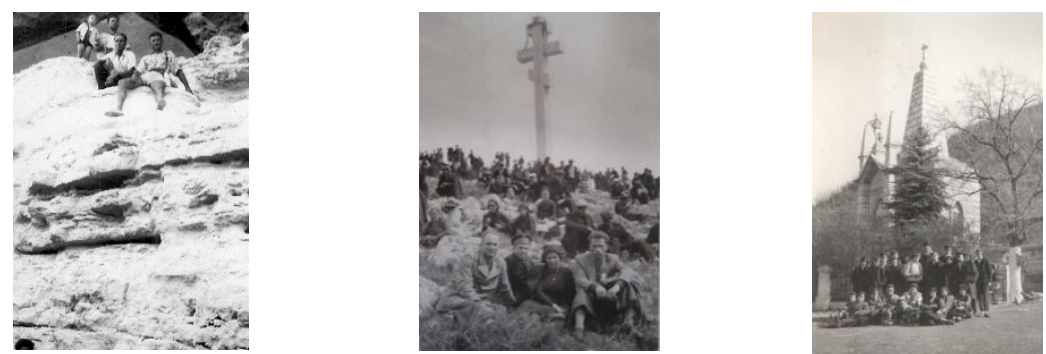

Figure 2. Photos from Aladzha cave monastery at Black sea resort Varna

1930s, commemorative patriotic gathering at Okolchitsa mount near Vratsa on 2-07-1945; students' excursion at memorial ossuary of Dryanovo monastery in early 1960s 


\section{HERITAGE MATERIALITY}

Reception of aesthetic value of material heritage do not necessarily lead to acknowledgement of its cultural nature as advanced communist medieval studies became objective academic field not being always linked to confessional theology of Eastern Orthodox Christian Church.

Expositions of sacred art rescue authentic pieces of churches and sepulchres, and sometimes even turn ancient or modern baths into museum chapels or rotundas, while archaeological excavations reveal altars and relocate initially immovable sacred objects or combines them with new movable liturgical artefacts. And hardly any expert, in theology or heritage, would doubt that any reflection from religious past has value to witness live traditions. Initially atheist socialist culture, having stopped international mobility and communications, having closed church parish and monastic centres, having limited local public festival gathering events by development of civic celebrations, and having also prevented confessional charity, education and recreation initiatives by redirecting their subsidising, prevented Bulgarian renovated elite form modernising any religious practice, including pilgrimage tourism that recently could not be based on uninterrupted religious traditions. While global pilgrimage had gradually become religious tourism, and even after loss of traditional culture along urbanisation, many denominations reinvented many customs and started facing a number of challenges of democratic postmodern societies, as alienation, immobilisation, environmental pollution, etc., post-socialist culture relied on developed recreational and heritage tourism, and reinvented attractive folk customs and art, but still had to reconstruct quite eclectic confessional practices.

\section{HERITAGE MOVABILITY}

Contemporary dynamics sometimes would even require that monuments of culture are predominantly movable and destructible, or replicas and stylisations are built instead of creating new artefacts and customs. Replicated sacred sites as mountains, cities, caves, fountains, etc., became common, typical and sometimes even large-scale projects, and also same pilgrimage attitudes are applied in case of émigré parishes, not just to meet attitudes of aesthetic spirituality, but to overcome any deficits of local religiosity. In Bulgaria Russian émigré heritage concentrated in 
sometimes closed crypt of the grave with relics of saint Seraphim of Sofia under the altar of Russian Saint Nicholas church in Sofia created small replica of the sepulchre in Kokalyane Saint Archangel Michael monastery, and also in several sacred places in Sofia and Plovdiv there is icon with a box so that people can ritually sent there their letters.

In similar way, chapel of Samaritan woman near Yambol memorial Russian monastery of Accession and saint Alexander Nevsky, once had been built in cave with miraculous holly well and decorated with religious sculptures and historical reliefs, and later was replicated in stone-carved chapel-like drinking well in Klissoura convent Saint Petka near Bankya in Sofia. Nowadays not only dependencies of Athonite monasteries usually have replicas of their most famous wonder-working icons, mainly for people who cannot afford any traveling. Devoted pilgrims replicate even whole church interiors, buildings and ensembles, and not only bring for donation some valuable object and miraculous icons that would not quite match existing sacred spaces, but make such copies in several parish churches, and that is also according to once existed traditions. Socialist culture valued tourist mobility according to well set cultural areas, and activities, as well as religious heritage was preserved and theoretically publically available, although limited to art and history, and accessed conditionally or occasionally. Well controlled sacred spaces were reduced to minimum and run by synodal and heritage authorities within clear cultural policy, providing regular and subsidised management than recently, when church property was regained also over sites that were not enough valuable to deserve museum or tourist socialisation. Constitutionally divided from state, Bulgarian Eastern Orthodox Christian church is only partially subsidised by state as several traditional local religious minorities and unlike many sacred sites around the world, local one that would not close during pandemic crisis in the spring 2020 are only those who were reopened or built in last three decades [Fig. 3, Fig. 4]. 

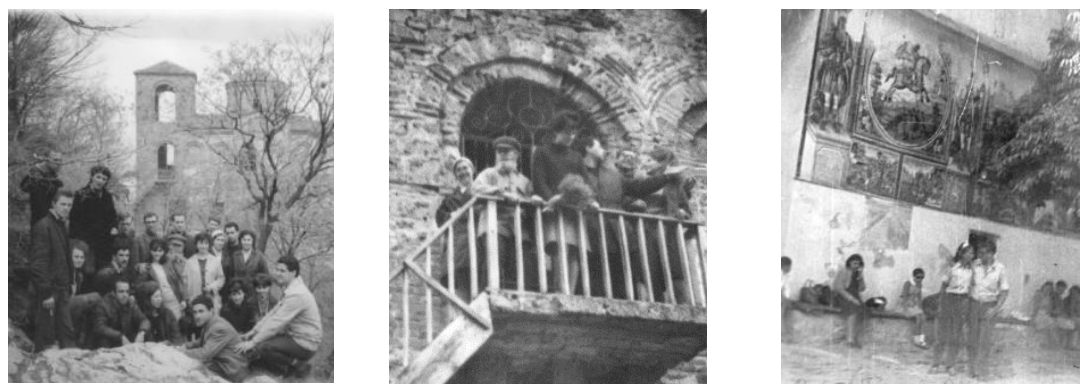

Figure 3. Educational and recreational youth trips in Bulgarian sacred sites, 1960s.
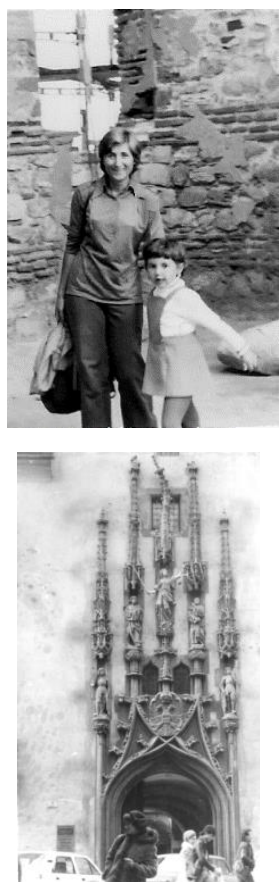
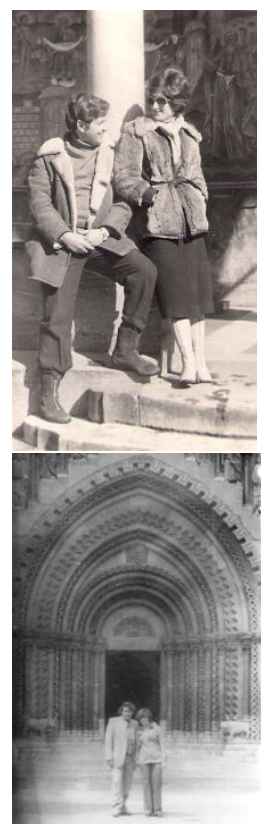
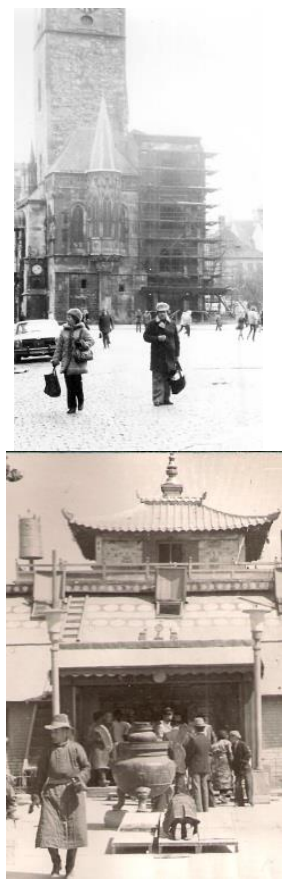

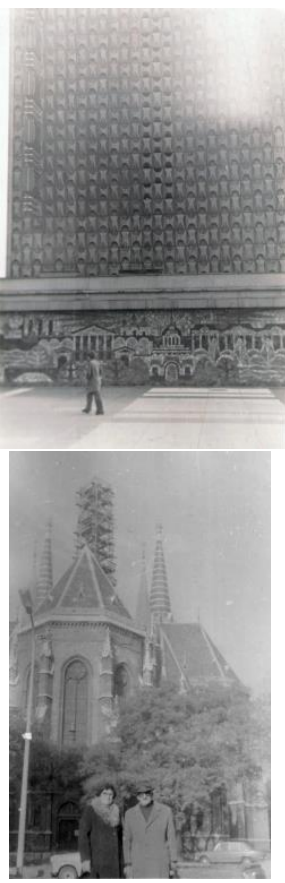

Figure 4. Photos from family trips in Bulgaria, Europe, and Asia in 1970s - 1980s

\section{SACRED HERITAGE VISIBILITY}

Ascetic spirituality is not genuinely demonstrative, neither it is judging any demonstrativeness; therefore it follows biblical principles of inner beauty and outer simplicity. What a pilgrim can observe and remember visually is 
supposed to be less, if the accent of spirituality is on internal transformation and advancement (Zaharieva, 2018). Although visual reception of church art goes together with visible expression of ethos, and supernatural revelation goes together with natural, confessional pilgrims should not be predominantly attracted by nature, inspired by weather, enthusiastic about sociability, astonished by art, or appealed by the zeal of clergy, at least not too religiously to lose balance and concentration of their healthy spiritual condition. Although it can be quite useful to intensify perception of church culture in order to make theology and church lifestyle understandable in recent popular language, incl. cultural, commercial business promotion attitudes to pilgrimage tourism still would not support any religious community, at least not directly.

Postmodern pilgrimage approaches value even direct and indirect selfies, formal and informal photographing, live and drone streaming and shared location or travel, professional and amateur reports and interviews, informative or commercial description of road maps and transport schedules, recomendations of tested products and shops, simple or more sophisticated infrastructure and technology advices. Insights vary from reflection on opportunities of urban of rural architectural or natural sightseeing, sportive climbing and walking combined with beautiful landscape around, to having rest or fun, art reception or creation, liturgical participation or religious socialisation, being helpful or disabled, needing of charity or providing donation, interpreting marginal issues as background or foreground of pilgrimage events as customs, and any other scope to sacred sites, providing authenticity of one's confessional or other expression. Accessibility of sacred spaces became important to postmodern pilgrims as long as they regained legitimation of public spaces Branding of a place diminishes by self- representations as object of sacred photograph [Fig. 5, Fig. 6].
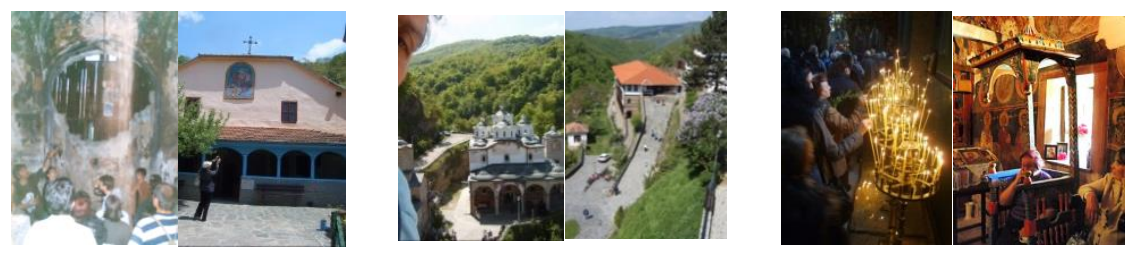

Figure 5. Changing behaviours and reflections on pilgrimages in early $21 \mathrm{c}$. 

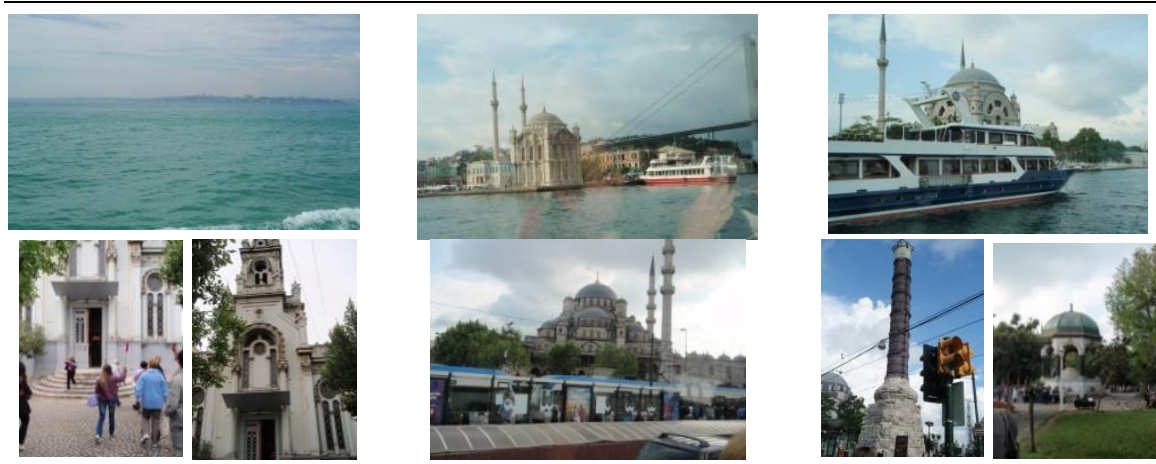

Figure 6. Fragmented pilgrimage reality in tourist photograph impressions

(taken from shared religious heritage in Istanbul, 2010. Photograph of travelling Bulgarian teachers is far from optimal actual representation, but provides informative and direct reflection unlike static professional photoes)

\section{IMMOVABILITY AND INVISIBILITY}

Competitive pilgrimage tourist product does not imply any questions why to visit again a sacred site in once explored destination, although religious mind would not normally need any visible reaffirmation of phenomena that are confessionally clear, and hence church ghettoization is related to ascetic isolation. Although religious people often like to travel together and thus consolidate their internal unity, often pilgrimage passion can affect negatively monastic and family life by neglect of one social unit to support another. And while movability and visibility of religiously valuable heritage objects like relics and icons could compensate the limitations of mobility of some believers and stimulate pilgrimage of others, invisible elements or whole sacred landscapes that do not attract all perceptions of whole church are not same as recreational tourist places that are similar, although there is such a typological tendency in new more private live parishes and monasteries that become rather a simple background to real clergy, believers, monks or nuns [Fig. 7]. 

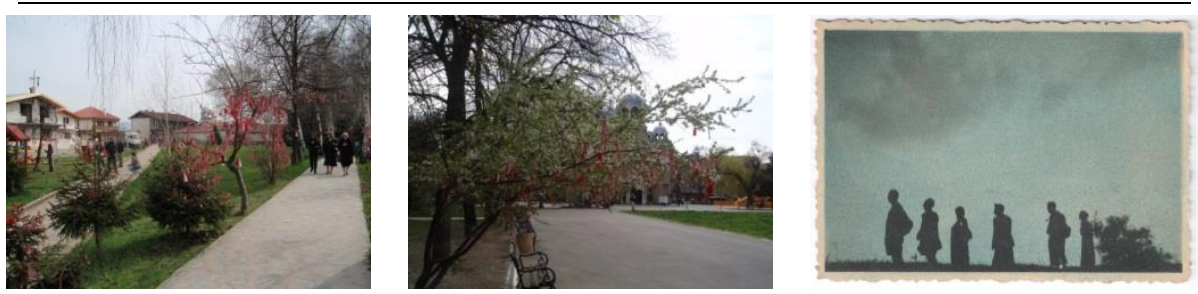

Figure 7. Pilgrims move from background to foreground reshape sites and landscapes

\section{BETWEEN CULTURAL AND RELIGIOUS IMMATERIALITY}

Only recently upon pandemic closure of spring 2020 would people realise how far had mobility become core civilisational value. Eastern Orthodox Christian pilgrimage was discussed as available recreational element of church ethos, or as unnecessary luxury practice in supposedly humble life of denominational community, and as non-traditional tourist and sportive practice that is to be blessed and spiritualised in the best pastoral interests. Confessional life used to be traditionally more focused in local church units and implying virtual awareness of belonging to glocal network, rather than influenced by post-socialist temptation to explore old sacred territorial orientations or attracted by postmodern value of church infrastructural support to wandering along restored ancient European tourist routes, which was quite an adequate response to many contemporary social human problems.

Mobility had been discussed at the same time as thread and support to cultural heritage, while pandemic crisis overturned global situation and pressed global religious mind shortly after glocal church unity deficits causing extreme schism conditions in Eastern Orthodox Christian Church rule and elite. Cultural clashes of diocesan dynamics and mobility and geopolitical overlapping resulted in splits that endangered pilgrimage and hence compromised traditional sustainability of sacred sites by bipolar territorial and ethnic competition between Slavonic and Greek speaking sister churches and fractions of local confessional communities. Unable to substantially limit glocal nature of contemporary pilgrimage and exchange, neither to benefit from positive religious communicative opportunities 
provided by contemporary technology and media, Eastern Orthodox Christian local communities did not either managed to resolve in unity actual religious challenge of pandemic enclosure as mobility regulation.

New circumstances set to escape effectively global health thread, as previous security measures could be better faced together as any other denominational risks and fears, by sharing models and innovations, and reach provision of consolation and experience even in cooperation with other religions and churches in more consolidated civic society, where particular religious efforts could adequately prevent negative consequences for denominational public image. Expression of public responsibility compensating religious presence became visible in personal feat of Greek medical doctor and church singer to lead the organisation of local pandemic lifestyle and limit almost immediately public asses to buildings of all denominations, including constitutionally state institution of Eastern Orthodox Christian community of the majority of population that had not suffered through communist cultural period in the near past. While traditional Greek festivity had not undergone forced transformation and local people were more accustomed to regular yearly celebrations, their church managed to reschedule Resurrection customs to the eve of Ascension, when actually Paschal days reach Pentecost period.

While in Greece 3 people remained at home and even standing before the screen with traditional transmission of Resurrectional services, while clergy were on screen, in Bulgaria necessary cultural effort was undertaken by disputably adequate, but quite timely social media representation of the civic social stand of one of main and popular political and state leaders. Home photo publically shared on Facebook depicted a grandfather as Christian celebrating Easter in open air at his yard with his family, like people had practiced in the past on many occasions: holding icon of Christ in his arm and candle in his hand, making a cross and saying few prayer-like words, not posing more than usually, not having dressed quite officially, neither wearing any traditional festive folk apparel, nor relying on ethno motives as it became

\footnotetext{
3 Even Greek kindergarten children learn about festive calendar and Lenten and Pentecost liturgical periods by personification of two sisters: Ladies Sarakosty and Pentikosty whom they portray every year in doll or ritual bread projects. Similar folk church traditions can be found and explored in every culture already adopted by past Eastern Orthodox Christian tradition.
} 
fashionable in last years. More patriotic politicians ${ }^{4}$ and activists protested against wearing of masks or enjoyed vital post-communist freedom of in situ live gonfalon attendance of Resurrection service, dressed accord. to the protocol.

\section{STATIC, RUINED, ABSENT, DAMAGED AND RECONSTRUCTED MATERIAL HERITAGE}

Material religious heritage in partitioned or artificial condition is sign of lack of life although it is supposed to be visible element of once live heritage. Nevertheless even extreme examples of tourist, cultural, economic or religious impropriety or misbalance between them demonstrated in sacred space deserve scholarly and organisational attention.

Yet before negative examples of religious objects of tangible or intangible, movable or immovable heritage had become precedent and mass practice, mechanisms of their emergence are to be studied, especially because better projects had not attracted subsidising and public approval. Postmodern tendencies to attract tourists even by dark religious tourism concern rather church ruins, than graveyards, which are sacred spaces, memorials and considered places of general pilgrimage, as far as honourable burials are welcome in many church and monastery surroundings, not as much as commemorative sculptures.

\section{RELIGIOUS PRACTICES AND LIFESTYLES MORE VISIBLE THAN HERITAGE AND PUBLIC IMAGE}

Religious customs represented in souvenirs and events, tourist reports, commercials, and promotions are not exactly the same when they are occasionally, privately, or even secretly practiced in more popular level and humbler manner as they origin form life of either central or marginal religious saint or divine personages. Imitation of old models is substantial for religious traditions in terms of authenticity of its messages and correctness of translation of sacred heritages, but creativity is also a contribution to development of denomination in more plausible social perspective. Future

\footnotetext{
${ }^{4}$ On military service, in fire department, and as capital mayor, he was probably experienced in negotiation with clergy about specific canonical conditions of management of sacred spaces, expressed also in regular providing of state airplane for bringing of Holly fire, considerable expense that in 2020 was redirected to economic support of pandemic reorganisations.
} 
industrial revolution implying cultural aspects of robotic relocation of human resources may imply positive impact on religious practices and lifestyles that had sacralised central social goals as mass hygiene and social cohesion centuries before civic society would realise substantial link of human capital with religious heritage and between denominational values and public images of confessional communities [Fig. 8].
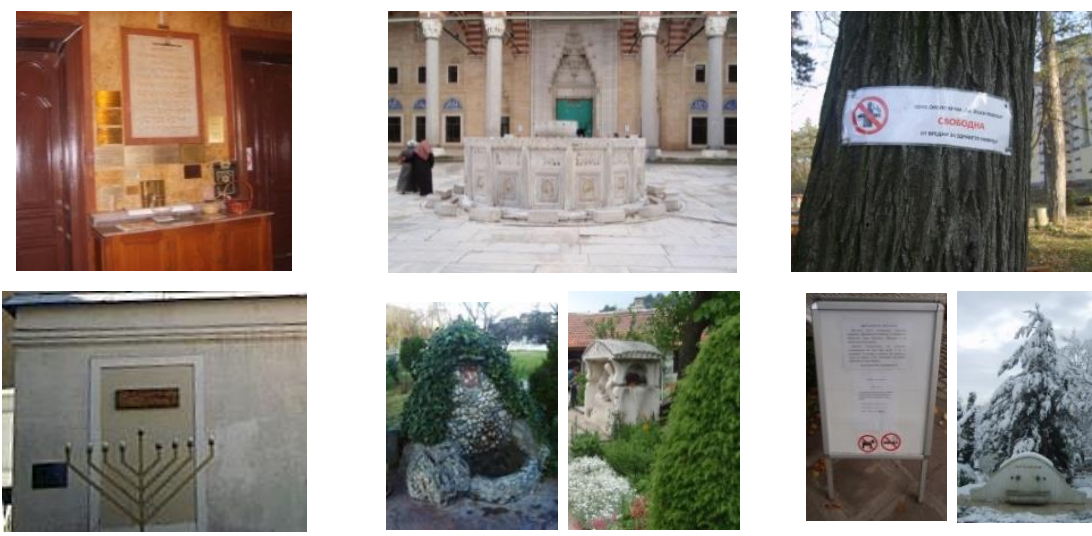

Figure 8. Ritual water and hygiene of sacred spaces

(not a most recent challenge, showing that religious restrictions have common human value)

Postmodern approaches of tourists, guides, believers, clergy and media to contemporary pilgrimage and its general public perception and tourist support will change after mass isolation on pandemic conditions in spring 2020 in regard with the variety of new attitudes to sacred sites, religious gatherings, and prayer sacramental practices. Extremely unpopular demodernisational tendencies are necessarily expected to increase as a result of cultural aspects of crisis visible initially in: appreciation of recovery of damaged nature, cleaning of contaminated areas, calming down of overcrowded urban places, escape of people in remote and abandoned rural and mountain spaces, sheltering of families at home, slowing down of human mobility. Reconsidering of previous functions of many zones and units, loss of identities and resources by activities and initiatives inadequate to temporary situation, over-dynamisation of media and revaluation of technologies and communications, virtualisation of education and 
academic communities had emergently reset cultural priorities, and to some extent enjoyed such unexpected opportunity of change.

\begin{tabular}{|c|c|c|}
\hline RELIGIOUS & CULTURAL & ECONOMIC \\
\hline Liturgical life and cycles & $\begin{array}{l}\text { Mobility as cultural } \\
\text { exchange }\end{array}$ & $\begin{array}{l}\text { Optimal touristic } \\
\text { exploitation }\end{array}$ \\
\hline Church attendance & Cultural enrichment & $\begin{array}{l}\text { Sustainable religious } \\
\text { tourism }\end{array}$ \\
\hline Confessional expression & Social cohesion & Mobility of tourists \\
\hline Sustainable sacred sites & Ritual practices & $\begin{array}{l}\text { Diverse specialised } \\
\text { tourism }\end{array}$ \\
\hline $\begin{array}{l}\text { Glocal confessional } \\
\text { legitimation }\end{array}$ & Artistic life and community & Quality of tourist product \\
\hline Ethnical identity & $\begin{array}{l}\text { Media representations of } \\
\text { faith }\end{array}$ & $\begin{array}{l}\text { Natural and cultural } \\
\text { heritage }\end{array}$ \\
\hline $\begin{array}{l}\text { Nationalist patriotic } \\
\text { feelings }\end{array}$ & Postmodern approaches & Local development \\
\hline Political preferences & $\begin{array}{l}\text { Valuable identity } \\
\text { revitalisation }\end{array}$ & Regional development \\
\hline Social mission & $\begin{array}{l}\text { Social cultural } \\
\text { reactualisation }\end{array}$ & $\begin{array}{l}\text { Geopolitical } \\
\text { development }\end{array}$ \\
\hline
\end{tabular}

\section{Figure 9. Social priorities as motivation for pilgrimage tourism}

New kind of forced critical consolidation of local and global civic societies and their sectors, as well as solidarity of their religious communities are to find common remodernisational cultural path to compensate for recent limitations in the fields of social care, childcare, education, sports, healthy lifestyles, subcultural communication, economy and business, technology, infrastructural and regional development. Amodernisational and even acculturation aspects of resent stagnation provide exceptional necessary perspective for contemplation and also a certain more static moment for rapid reconsideration of values, strategies, visions and missions, and post-pandemic post-critical cultural situation is expected to become even more fictional, instead of more general normalisation following the actual normalisation in some aspects of that kind of social experiment. Recent active testing of human values and virtues, proactive behaviour and assertive communication skills, non-discriminative attitudes and socially constructive worldviews will reflect also in various practices of contemporary pilgrimage as kind of religious tourism that will reconsider once again the 
role of future overmodernised religious centres according to their potential to support social priorities [Fig. 9]

\section{МИTEPATYPA / REFERENCES}

Benovska-Sabkova, M. (2006). Mountain tourism, urban culture, and national feelings: Climbing up Mount Vitosha near Sofia as a Modern Pilgrimage (In Bulgarian). - In: Bulgarian ethnology, 2, pp. 71 - 81, ISSN 1310-5213 // [Беновска-Събкова, М. П^анински туризьм, градска култура и национални чувства: "изкачване на Витоша" като фрорма на съвременно поклонничество.].

Benovska-Sabkova, M. (1998). Tradition as a means for survival in conditions of economic crisis in Bulgaria (In Bulgarian). - In: Bulgarian ethnology, 3 - 4, pp. 53 64, ISSN 1310-5213 // [Традицията като среАство за оцеляване в условията на икономическа криза в България].

Caputo, J. D. (2015). Hoping Against Hope: Confessions of a postmodern pilgrim. Augsburg: Fortress press, ISBN: 978-145-149-915-5.

Demirev, V. G. (2019). The topos "The monastery": Lost in the past or with a chance in the present (On materials from Sliven region) (in Bulgarian). - Bulgarian folklore, 3 , pp. 273-293, ISSN 0323-9861 // [Аемирев, В. Топосьт "Монастиря“ - изгубен в миналото или с шанс в настоящето (По материали от Сливенско)];

Demirev, V. G. (2014). Local knowledge and sacral topography in the region of Sliven (in Bulgarian), Sliven: Zhazhda. ISBN 978-954-795-438-0 // [Местно знание и сакрална топографиия в Сливенско]

Garvanova, M. Z., \& Shapkalova, S. (2015). Crisis of religious values in contemporary Bulgaria (in Bulgarian). In Nazaraska, Zh, \& Shapkalova, S. Eds. Harmony in diversity. Sofia: UniBIT - O pismeneh, pp. 27 - 53, ISBN 978-619-185-151-5 // [Гарванова, М., \& Шапкалова, С. Кризата на религиозни ценности в съвременна България. В: Ж. Назьрска, \& Шапкалова, С. Сьст. Хармония в различията].

Kalkandzhieva, D. V. (2002). The Millennium of the death of saint loan of Rilla (May 26, 1946). - Bulgarian Historical Review, 3-4, pp. 188-206, ISSN 0204-8906.

Kōiva, M., Kuperjanov, A., \& Liisa Vesik, L. (2018). Sacred Places: Destinations of travel and pilgrimage in Bulgaria. In Anastasova, E., \& Toncheva, S., Eds. Balkan and Baltic states in united Europe. Histories, religions, and cultures. 2. Sofia: Paradigma, 2018, ISBN 978-954-326-372-1, pp. 121 - 134.

Köiva, M. (2016). Pilgrimage in the secularized society: Revival and specifics (in Bulgarian). - Bulgarian folkore, 1, pp. 64 - 77, ISSN 0323-986] // [Къйва, М. 
Поклонничеството в секуларизираното общество - възражлане и особености].

Koleva, M. (2011). Guest room from Koprivshtitsa in Rilla monastery (in Bulgarian). Proceedings of National history museum, 23, pp. 231 - 252, ISSN 1311-5219 // [Колева, М. Копривщенска гостна стая в Рилския манастир].

Luleva, A. (2012). Transformation in the culture of informality in post-socialist Bulgaria: A case study on the Borovets tourist resort (in Bulgarian). - Bulgarian ethnology, 3 - 4, pp. 57 - 72, ISSN 1310-5213 // [^улева, А. Неорормалност, АженАьр, туризьм: Примерьт на курорта Боровец].

Mustonen, P. (2006). Volunteer Tourism: Postmodern Pilgrimage? - Journal of Tourism and Cultural Change, 3, pp. 160-177.

Nikolchev, D. (2015). Exarch Stephen under the care of state security (in Bulgarian). Punlisher: Millitary press, Sofia, Bulgaria, ISBN 978-954-509-546-7 // [Екзарх Стефран пол "грижите" на Аьржавна сигурност].

Nikolova, M. (2013). Contemporary practices of religious travelling in Bulgaria: between pilgrimage and tourism (In Bulgarian) - SeminarBG, 9. ISSN 1313-9932. 28 November $2013 \quad$ - $\quad$ [https://www.seminar-bg.eu/spisanie-seminarbg/broy9/item/395-savremenni-praktiki-na-religiozno-patuvane-v-balgariyamezhdu-poklonnichestvoto-i-turizma.html, (Last view: 24.04.2020)] // [Съвременни практики на религиозно пьтуване в България: межАу поклонничеството и туризма].

Peykov, V. Ed. (2016). Meetings with elder Nazary (In Bulgarian). Publisher: Tavor, Sofia, Bulgaria, ISBN 978-619-900-683-2 // [Пейков, В. Срещи със стареца Назарий].

Radisavlevich-Chiparazovich, D. (2014). Mixed pilgrimage in Serbia on the example of two holy sites (Dzhunis and Tekie) (In Russian) - State, religion, Church in Russia and abroad. 2(32), pp. 139 - $160, \quad$ ISSN 2073-7203 [http://www.intelros.ru/pdf/GosRelTserkov/2014_2/8.pdf, (Last view: 13.04.2020)] // [Ралисавлевич-Чипаризович, А. Смешанное паломничество в Сербии на примере Авух святынь (Ажунис и Текие). - Государство, религия, Церковь в России и за рубежом].

Rilets, K. (2015/1939). Various categories of visitors of Rilla monastery (in Bulgarian). Eastern Christian Orthodox missionary, 8, 9 - [ https://budiveren.com/index.php?option=com content \&view=article\&id=1258:1 \& catid=46:2010-02-23-19-420-2\&ltemid=77,

https://budiveren.com/index.php?option=com content \&view=article \&id=1261:2\& catid $=46 \&$ ltemid $=77$, https://budiveren.com/index.php?option=com content\&view=article\&id=1263:3\& 
catid=468ltemid=77, (Last view: 23.04.2020)] // [Рилец, К. Различни категории посетители на Рилския манастир. - Православен мисионер, 8, 9,].

Simeonova, G. G. (2000). Traditional feasts in condition of change (in Bulgarian). Publisher: BAS, Sofia, Bulgaria, ISBN 978-954-430-685-4 // [Симеонова, Г. Г. Традиционните празници в сьстояние на промяна].

Valchinova, G. I. (2006). Balkan visionaries and prophetesses form 20th century (in Bulgarian). Publisher: Bulgarian bestseller, University Press, ISBN 954-463-014-7 // [Вьлчинова, Г. И. Балкански ясновиАки и пророчици от XX век];

Valchinova, G. I. (1999). Laudae Znepolensia: Local religion and identity in Western Bulgaria (in Bulgarian). Publisher: BAS, Sofia, Bulgaria, ISBN 954-430-644-7 // [Знеполски похвали: ^окална религия и иАентичност в ЗапаАна България].

Velinov, I. I. (2012). Pilgrimage in Bulgaria since 1990: A cultural transformation (in Bulgarian). Publisher: New Bulgarian University, PhD thesis, Sofia, Bulgaria. Resume // [Поклонничеството в България слеА 1990: Културна трансорормация. Авторефрерат]. Accessed April 26, 2020. Retrieved from: https://core.ac.uk/reader/20441460 (In Bulgarian).

Zaharieva, D. (2018). Pilgrimage as focus of Eastern Orthodox Christian culture nowadays (In Buulgarian). - Light, 2, - [https://www.svet.bg/пок^онничествотокато-средоточие-на/, (Last view: 23.04.2020)] // [Захариева, А. Пок^онничеството като средоточие на правос^авна култура Анес. - Свет]. 


\section{КУАТУРНО-ИСТОРИЧЕСКО НАСАЕАСТВО: \\ ОПАЗВАНЕ, ПРЕАСТАВЯНЕ, АИГИТААИЗАЦИЯ}

\section{CULTURAL AND \\ HISTORICAL \\ HERITAGE}

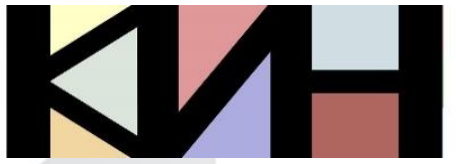

PRESERVATION PRESENTATION DIGITIZATION
Материалите в сборника са обект на авторско право. Разрешава се безвъзмезАното ползване на техни електронни/ хартиени копия само за лична употреба или обучение, при пь^но цитиране на текущата страница и слеА писмена декларация от цитиращия за Аипса на търговски намерения. За копиране пол Аруга фрорма, препубликуване или публикуване на сървъри се изисква писмено разрешение и/или заплащане.

() Авторски колектив, 2020 Техническо реАактори: Николай Ноев Калина Сотирова-Вълкова
This work is subject to copyright. Open and free of charge use of digital/hard copies of publications is granted only for personal or educational use, with full citation of the current page, and after written declaration of the quoting side for not-commercial Intention. For any other reproducing types, republishing, photocopying, recording, or any other storage retrieval system/ server written permission and/or fee is required.

(C) Authors` Group, 2020

Technical editors:

Nikolay Noev

Kalina Sotirova-Valkova

\section{Научна пореАица: том 6, брой 1 (8)/2020 Science series: vol. 6 , issue $1(8) / 2020$}

